\title{
EVALUASI KEBIJAKAN PEMBERLAKUAN PEMBATASAN KEGIATAN MASYARAKAT (PPKM) DARURAT JAWA-BALI DALAM MENANGGULANGI COVID-I9 DI KOTA DENPASAR
}

\author{
EVALUATION OF POLICY FOR IMPLEMENTING RESTRICTIONS OF JAVA-BALI \\ EMERGENCY COMMUNITY ACTIVITIES (PPKM) IN MANAGING COVID-I 9 IN \\ THE CITY OF DENPASAR
}

\section{Ketut Riris}

\section{Pundarini Dewi ${ }^{*}$}

\section{Nyoman}

Sunarta 2

* 1,2 Universitas Pendidikan

Nasional, Denpasar, Indonesia

*email:

ririspundarini00@gmail.com

\section{Kata Kunci:}

Covid-19

Kebijakan Pemerintah

Pemberlakuan Pembatasan

Kegiatan Masyarakat (PPKM)

\section{Keywords:}

Covid-19

Government Policy

Implementation of Restrictions on

Community Activities (PPKM)

\section{Accepted}

June 202I

\section{Published}

October 2021

\begin{abstract}
Abstrak
Pandemi Covid-19 telah menjadi masalah di hampir semua negara di dunia. Pemerintah Indonesia telah menetapkan kedaruratan kesehatan masyarakat terkait Covid-19. Dalam hal ini, Pemerintah Kota Denpasar memberlakukan Pemberlakuan Pembatasan Kegiatan Masyarakat. Pemberlakuan Pembatasan Kegiatan Masyarakat merupakan langkah strategis yang dilakukan pemerintah untuk menekan penyebaran pandemi virus corona atau Covid-19. Penelitian in bertujuan untuk mengetahui penerapan kebijakan PPKM Darurat Jawa-Bali dalam penanggulangan wabah Covid-19 di Kota Denpasar. Adapun metode penelitian yang digunakan adalah deskriptif kualitatif. Penelitian ini menggunakan sumbersumber data yang berasal dari jurnal ilmiah, literatur buku, situs web resmi yang yang kemudian digambarkan melalui teknik deskriptif analisis yang dilakukan secara menyeluruh untuk memberikan suatu pemahaman mengenai fenomena yang di alami oleh subjek penelitian yaitu menggambarkan evaluasi penerapan kebijakan PPKM Darurat di Kota Denpasar. Hasil penelitian menjelaskan bahwa penerapan kebijakan PPKM Darurat Jawa-Bali di Kota Denpasar meliputi beberapa hal yaitu sektor esensial 50\% WFO dengan pengetatan prokes, sektor kritikal diperbolehkan 100\% WFO dengan pengetatan prokes, supermarket, pasar tradisional, toko kelontong, dan pasar swalayan kapasitas pengunjung maksimal $50 \%$ dan jam operasional sampai pukul 20.00. Penerapan kebijakan PPKM dalam penanggulangan wabah Covid- 19 di Kota Denpasar sudah berjalan efektif.
\end{abstract}

\footnotetext{
Abstract

The Covid-1 9 pandemic has become a problem in almost all countries in the world. The Indonesian government has declared a public health emergency related to Covid19. In this case, the Denpasar City Government enforces the Enforcement of Restrictions on Community Activities. The imposition of restrictions on community activities is a strategic step taken by the government to suppress the spread of the corona virus or Covid-19 pandemic. This study aims to determine the implementation of the Java-Bali Emergency PPKM policy in dealing with the Covid-19 outbreak in Denpasar City. The research method used is descriptive qualitative. This study uses data sources originating from scientific journals, book literature, official websites which are then described through descriptive analysis techniques carried out thoroughly to provide an understanding of the phenomena experienced by research subjects, namely describing the evaluation of the implementation of Emergency PPKM policies. in Denpasar City. The results of the study explain that the implementation of the JavaBali Emergency PPKM policy in Denpasar City includes several things, namely the essential sector of 50\% WFO with tightening procedures, critical sectors are allowed to $100 \%$ WFO with tightening procedures, supermarkets, traditional markets, grocery stores, and supermarkets with visitor capacity. maximum $50 \%$ and operating hours until 20.00. The implementation of the PPKM policy in dealing with the Covid-19 outbreak in Denpasar City has been running effectively.
} 


\section{PENDAHULUAN}

Pandemi Covid-19 saat ini menjadi ancaman global terbesar yang masih menghantam berbagai sektor. Sejak awal kemunculannya pada akhir 2019 lalu, virus yang menyerang sistem pernapasan manusia ini telah menyebar luas hampir ke seluruh negara di dunia dengan lebih dari 127 juta kasus di seluruh dunia dan lebih dari 2,7 juta kematian per 31 Maret 202I (Kompas, 202I). Penularan Covid-19 antar manusia yang terjadi sangat cepat telah menimbulkan dampak luar biasa bagi peradaban manusia. Tidak hanya masalah kesehatan, pandemic Covid-19 juga berdampak signifikan terhadap aktivitas perekonomian, pendidikan, perdagangan, sosial masyarakat, dan sektor lainnya (Dinas Kesehatan Provinsi Bali, 2020). Pemerintah Pusat dalam merespon fenomena pandemi Covid-19 ini menetapkan PPKM Darurat sebagai opsi kebijakan yang tertuang dalam Instruksi Menteri Dalam Negeri Nomor I5 Tahun 202I tentang Pemberlakuan Pembatasan Kegiatan Masyarakat Darurat Corona Virus Disease 2019 Di Wilayah Jawa dan Bali (Suni, 2020). Kota Denpasar menginisiasi kebijakan Pemberlakuan Pembatasan Kegiatan Masyarakat (PPKM) yang tertuang dalam Peraturan Gubernur Bali Nomor 09 Tahun 2021 tentang Pemberlakuan Pembatasan Kegiatan Masyarakat Darurat Corona Virus Disease 2019 Dalam Tatanan Kehidupan Era Baru Di Provinsi Bali (Peraturan Gubernur Bali, 2021). Opsi kebijakan ini diharapkan dapat memutus rantai penyebaran virus corona yang terus meningkat dalam waktu belakangan ini (Kompas, $2021)$.

Keberhasilan implementasi kebijakan penanganan Covid-19 sangat membutuhkan respon yang baik dari masyarakat selaku kelompok sasaran kebijakan (target group). Namun, faktanya masih banyak masyarakat yang tidak mengindahkan kebijakan-kebijakan pemerintah untuk memutus rantai penularan Covid-19 (Kompas,
2020). Masih terdapat masyarakat yang mengabaikan protokol kesehatan saat beraktivitas di luar rumah, dan bahkan nekat pergi ke luar daerah untuk mudik dan liburan ke tempat keramaian (Zahrotunnimah, 2020).

Berdasarkan permasalahan di atas, maka penting untuk menganalisis kebijakan Pembatasan Kegiatan Masyarakat (PPKM) Darurat Jawa-Bali di Kota Denpasar apakah berfungsi secara efektif sebagaimana tujuannya yaitu dalam rangka memutus rantai penularan Covid-19 yang selama ini menjadi dilema pemerintah dalam mengambil kebijakan terkait penanganan Covid-I9. Adapun kasus dalam penelitian ini adalah pada pelaksanaan kebijakan PPKM Darurat Jawa-Bali di Kota Denpasar.

\section{METODOLOGI PENELITIAN}

Dalam penelitian kali ini, penulis menggunakan metode penelitian kualitatif. Penelitian kualitatif merupakan suatu metode penelitian ilmu-ilmu sosial yang mengumpulkan dan menganalisis data berupa katakata (lisan maupun tulisan) dan perbuatan-perbuatan manusia. Penelitian ini menggunakan sumber-sumber data yang berasal dari jurnal ilmiah, literatur buku, situs web resmi yang kemudian digambarkan melalui teknik deskriptif analisis. Teknik deskriptif analisis merupakan teknik penelitian yang dilakukan secara menyeluruh untuk memberikan suatu pemahaman mengenai fenomena yang di alami oleh subjek penelitian yaitu menggambarkan evaluasi penerapan kebijakan PPKM Darurat di Kota Denpasar. 


\section{HASIL DAN PEMBAHASAN}

\section{A. Evaluasi Kebijakan Pemberlakuan \\ Pembatasan Kegiatan Masyarakat (PPKM) \\ Darurat Jawa-Bali di Kota Denpasar}

PPKM Darurat atau Pemberlakuan Pembatasan Kegiatan Masyarakat merupakan tindaklanjut Gubernur Bali dalam menerapkan kebijakan yang dikeluarkan oleh Pemerintah Pusat yang tertuang dalam Instruksi Menteri Dalam Negeri Nomor 15 Tahun 202I tentang Pemberlakuan Pembatasan Kegiatan Masyarakat Darurat Corona Virus Disease 2019 Di Wilayah Jawa Dan Bali untuk memutus rantai penyebaran virus corona. Melihat capaian angka positif Covid-19 yaitu 9,72\% sementara kasus aktif dunia berada pada posisi $17,34 \%$ maka kebijakan ini harus dilaksanakan secepatnya dengan target penurunan penambahan kasus konfirmasi harian kurang dari 10.000 kasus per hari (Kompas, 202I). PPKM Darurat ini dikeluarkan dengan mempertimbangkan 2 (dua) hal yaitu pertama semakin tingginya angka penularan Covid-19 di wilayah Provinsi Bali yang ditandai dengan meningkatnya angka kasus penularan per hari, dan kedua semakin pentingnya bagi semua pihak untuk menjaga kesehatan, kenyamanan, keamanan dan keselamatan bagi masyarakat Bali (Kompas,202I). Kebijakan ini mulai diberlakukan pada tanggal 3 Juli hingga 20 Juli khusus di wilayah Jawa dan Bali. Adapun kegiatan yang diatur dalam kebijakan PPKM Darurat meliputi :

a. pelaksanaan kegiatan belajar mengajar (Sekolah, Perguruan Tinggi, Akademi, dan Tempat Pendidikan/Pelatihan) dilakukan secara daring/online;

b. pelaksanaan kegiatan pada sektor non esensial diberlakukan 100\% (seratus persen) Work From Home (WFH);

c. pelaksanaan kegiatan pada sektor :
I. esensial seperti keuangan dan perbankan, pasar moda, sistem pembayaran, teknologi informasi dan komunikasi, perhotelan non penanganan karantina Covid-19, industri orientasi ekspor diberlakukan 50\% (lima puluh persen) maksimal staf Work From Office (WFO) dengan protokol kesehatan secara ketat;

2.esensial pada sektor pemerintahan yang memberikan pelayanan publik yang tidak bisa ditunda pelaksanaannya diberlakukan 25\% (dua puluh lima persen) maksimal staf WFO dengan protokol kesehatan secara ketat;

3.kritikal seperti energi, kesehatan, keamanan, logistik dan transportasi, industri makanan, minuman dan penunjangnya, petrokimia, semen, objek Vital nasional, penanganan bencana, proyek strategis nasional, konstruksi, utilitas dasar (listrik dan air), seda industri pemenuhan kebutuhan pokok masyarakat sehari-hari diberlakukan 100\% (seratus persen) maksimal staf Work From Office (WFO) dengan protokol kesehatan secara ketat;

4.untuk supermarket, pasar tradisional 3 toko kelontong, dan pasar swalayan yang menjual kebutuhan sehari-hari dibatasi jam operasional sampai pukul 20.00 Wita dengan kapasitas pengunjung 50\% (lima puluh persen); dan

5.untuk apotek dan toko obat dapat buka selama 24 jam.

d. pelaksanaan kegiatan makan/minum di tempat umum (warung makan, rumah makan, kafe, pedagang kaki lima, dan lapak jajanan) baik yang berada pada lokasi tersendiri maupun yang berlokasi pada pusat perbelanjaan/mall hanya menerima delivery/take away dan tidak menerima makan di tempat (dine-in); 
e. kegiatan pada pusat perbelanjaan/mall/pusat perdagangan ditutup sementara kecuali akses untuk restoran, supermarket, dan pasar swalayan dapat diperbolehkan dengan memperhatikan ketentuan pada poin c.3 dan poin d;

f. pelaksanaan kegiatan konstruksi (tempat konstruksi dan lokasi proyek) beroperasi 100\% (seratus persen) dengan menerapkan protokol kesehatan secara lebih ketat;

g. aktifitas keagamaan di tempat ibadah (Masjid, Mushola, Gereja, Pura, Vihara, dan Klenteng serta tempat umum lainnya yang difungsikan sebagai tempat ibadah) dilaksanakan dengan melibatkan jumlah orang yang sangat terbatas dan atas seizin Satgas Covid-19 Kabupaten/Kota;

h. fasilitas umum (area publik, taman umum, tempat wisata umum, dan area publik lainnya) ditutup sementara;

i. kegiatan seni, budaya, olahraga dan sosial kemasyarakatan (lokasi seni, budaya, sarana olahraga dan kegiatan sosial yang dapat menimbulkan keramaian dan kerumunan) ditutup sementara;

j. transportasi umum (kendaraan umum, angkutan masal, taksi (konvensional dan online), dan kendaraan sewa/rental) diberlakukan dengan pengaturan kapasitas maksimal 70\% (tujuh puluh persen) dengan menerapkan protokol kesehatan secara lebih ketat;

k. resepsi pernikahan dihadiri maksimal 30 (tiga puluh) orang dengan menerapkan protokol kesehatan secara lebih ketat dan tidak menerapkan makan di tempat resepsi, penyediaan makanan hanya diperbolehkan dalam tempat tertutup, dan untuk dibawa pulang;
I. bagi yang melakukan perjalanan dengan transportasi udara wajib menunjukkan kartu vaksin (minimal vaksin suntik I), surat keterangan hasil negatif uji swab berbasis PCR paling lama $2 \times 24$ jam sebelum keberangkatan. Sedangkan dengan transportasi darat dan laut wajib menunjukkan kartu vaksin (minimal vaksin suntik I), surat keterangan hasil negatif uji swab berbasis PCR atau hasil negatif uji Rapid Test Antigen paling lama $2 \times 24$ jam sebelum keberangkatan. Untuk sopir kendaraan logistik dan transportasi barang lainnya dikecualikan dari ketentuan memiliki kartu vaksin;

m. untuk menunjukan keakuratan dan memastikan keaslian hasil negatif uji swab berbasis PCR atau hasil negatif uji Rapid Test Antigen, surat keterangan tersebut wajib dilengkapi dengan Barcode/QRCode; dan

n. tetap memakai masker dengan benar dan konsisten saat melaksanakan kegiatan di luar rumah, serta tidak diizinkan penggunaan face shield tanpa menggunakan masker.

Penerapan kebijakan PPKM ini dilakukan dengan melibatkan beberapa pihak. Pada penerapan kebijakan kali ini pemantauan dan penindakan dilakukan di 6 pos pantau, yakni pos pantau induk, pos A Yani, Pos Mahendradata, Pos Catur Muka, Pos Imam Bonjol, dan Pos Biaung (Balipost, 202I).

Pada setiap pos pemantauan akan dikerahkan sebanyak I34 personel, pada tahap pertama terdiri dari Dinas Perhubungan, Polri, TNI, Satpol PP, BPBD, Dinas Kesehatan, Pecalang, dan Kesbangpol. Dimana pelaksanaan penjagaan dibagi ke dalam dua shift per hari, yakni pukul 07.00-13.00, dan pukul 13.00-22.00 WITA, dimana dalam satu shift terdiri atas 67 personel. Sementara tahap selanjutnya akan dilaksanakan mulai tanggal 15 Juni 
2020 hingga selesai dengan penindakan, baik represif maupun kuratif di seluruh wilayah Kota Denpasar (Balipost, 2021). Pada pelaksanaan kedua ini akan dilakukan di II pos pantau dengan jumlah personel yang dilibatkan sebanyak 216 orang (Kompas, 202I).

Penjagaannya juga menggunakan sistem shift yang dibagi ke dalam dua shift per hari dengan jumlah personel 108 orang per shiftnya. Pembatasan kegiatan yang dilakukan mulai dari kegiatan bekerja dari rumah (work from home) belajar dari rumah (study from home), pembatasan kegiatan agama, pembatasan kegiatan di tempat umum, dan pembatasan mobilisasi masyarakat. Namun jika ada hal yang mendesak, maka setiap masyarakat harus tetap menaati protokol kesehatan dengan memakai masker, menjaga jarak (physical distancing) dan mengikuti perilaku hidup bersih. Kegiatan PPKM ini dikoordinasikan kepada instansi lain, antara lain Kepala Desa, Lurah, Desa Adat, TNI/Polri, serta perangkat organisasi lainnya (Suni, 2020).

$\mathrm{Hal}$ ini dilakukan tentunya untuk memberikan satu informasi yang jelas agar tidak menimbulkan keambiguan. Selain itu diikutsertakannya instansi TNI/Polri dengan tujuan untuk menciptakan keamanan selama pelaksanaan PPKM. Kegiatan pertama yang harus dilakukan adalah sosialisasi. PPKM ini dimulai dengan mensosialisasikan kepada pihak-pihak yang terlibat seperti Ketua Tempekan/Kelompok Krama/Dusun Lingkungan/Kelurahan, Kaling, Kadus, Kelihan, Bendesa, Prebekel setempat di masing-masing kecamatan di Bali. Hal ini ientu harus diinformasikan agar masyarakat tidak kaget akan kebijakan baru yang akan diterapkan. Selain itu sosialisasi dilakukan untuk menginformasikan teknis pelaksanaan PPKM ini. Teknis pelaksanaan sangat penting untuk disampaikan agar tidak adanya kekeliruan ataupun kurangnya informasi jika ada masyarakat yang menanyakan tentang kebijakan ini. Dan juga dibentuk Satuan Tugas (Satgas) Gotong Royong Pencegahan Covid- 19 berbasis Desa Adat dalam penanggulangan pandemi virus corona.

Selain dilakukannya pengawasan tentang pemakaian masker, dilakukan juga pengawasan mengenai mobilisasi masyarakat. Mobilisasi masyarakat yang dimaksud adalah masyarakat yang ke luar atau masuk wilayah desa/lurah/desa adat. Mobilisasi masyarakat juga menjadi indikator terjadinya penularan Covid-19 karena masyarakat berpindah dari satu tempat ke tempat lainnya. Terdapat juga larangan masyarakat tanpa tujuan jelas. Setiap masyarakat yang ke luar wilayah desa harus dengan tujuan jelas yang ditunjukkan dengan Surat Keterangan Kerja atau surat yang menyatakan bahwa terdapat keperluan mendesak yang mengharuskan masyarakat untuk ke luar rumah. Masyakarat akan di check surat-surat yang mendukung untuk melakukan mobilisasi. Jika tidak ada tujuan yang jelas, masyarakat akan diminta untuk kembali ke rumah masing-masing. Dengan pembatasan kegiatan mobilisasi ini tentunya dapat mencegah penularan virus ini. Pengecekan surat-surat biasanya dilakukan di pos-pos pantau yang sudah ditetapkan. Masyarakat akan dihimbau untuk menunjukkan surat-surat keterangan dan akan diperiksa. Selain itu, pengecekan ini tetap diatur jaraknya yaitu sekitar Imeter sehingga tidak menimbulkan kerumunan.

Namun pada kenyataannya masih saja ada masyarakat yang tidak memperhatikan jarak yang sudah dihimbau. Bahkan ada masyarakat yang cepatcepat atau mungkin lupa membawa surat dan memaksa untuk masuk wilayah tersebut. Tentu saja petugas tetap mengikuti aturan dengan memberikan sanksi baik berupa teguran ataupun sanksi 
administratif. Kesadaran akan menjaga jarak apalagi saat situasi urgent perlu diperhatikan. Pemberlakuan Pembatasan Kegiatan Masyarakat juga dilakukan kepada kendaraan yang membawa penumpang penuh ataupun aktivitas kendaraan barang. Pembatasan pada kendaraan penumpang penuh ini dilakukan agar tidak terjadi penularan virus corona yang lebih massif lagi. Adanya pembatasan hingga 50\% dari total kapasitas muatan. Hal ini juga diawasi dengan ketat oleh petugas terkait (Harahap, 2020). Larangan membawa penumpang penuh juga diterapkan, khususnya bagi kendaraan barang, dan hal ini memerlukan pantauan ketat petugas, karena bisa saja kendaraan barang tersebut mengangkut masyarakat yang baru saja pulang mudik atau pun kegiatan lainnya yang bisa saja menjadi sumber penyebaran virus.

Pembatasan aktivitas kendaraan barang ini juga sangat diawasi. Apalagi untuk kendaraan yang membawa barang dari luar yang akan masuk ke Denpasar. Kendaraan barang wajib membawa Surat Keterangan yang mendukung untuk dapat masuk wilayah Kota Denpasar. Selain itu diperhatikannya kebersihan dan hygiene barang tersebut. Kebersihan dan hygiene ini harus diperhatikan karena bisa saja pengemudi lolos untuk masuk wilayah Denpasar, namun barang yang diangkut terinfeksi virus corona.

Selain itu, tempat makan, restoran, rumah makan, cafe, warung makan, depot, pedagang kaki lima usaha makanan dan minuman, dan mall diperbolehkan buka hanya sampai jam 8 malam. Dan telah dilakukan pengawasan ketat terhadap semua unit usaha tersebut. Setelah jam 8 malam, akan dilakukan patroli desa dan jika tempat makan, restoran, rumah makan, cafe, warung makan, depot, pedagang kaki lima usaha makanan dan minuman, dan mall masih ada yang beroperasi, maka akan dikenakan sanksi larangan berjualan. Pembatasan ini dilakukan secara intensif dan ketat, karena melihat kondisi kadang masih ada pedagang-pedagang yang sembunyi-sembunyi tetap buka lebih dari jam 8 malam. Selain pengawasan dari pihak petugas, perlu adanya kesadaran dari masyarakat itu sendiri terutama pemilik rumah makan, restoran, cafe, warung makan, depot, pedagang kaki lima usaha makanan dan minuman, dan mall ini mengenai batas waktu jam berjualan tersebut. Hal ini mengingat kondisi riil bahwa jenis usaha seperti mall, tidak bisa tutup tepat jam 8 malam karena masih ada pelanggan yang berbelanja dan pelanggan tersebut tidak peduli terhadap kebijakan PPKM Darurat.

Selanjutnya pembatasan kerumunan masyarakat juga sangat diawasi saat pelaksanaan PPKM ini. Kerumunan masyarakat dianggap dapat menjadi sumber penularan Covid-19 karena berkumpulnya orang-orang dalam jumlah yang banyak. Pembatasan terhadap kerumunan ini dilakukan melalui pembatasan jumlah (kuantitas) masyarakat pada satu tempat. Jumlah (kuantitas) yang dimaksud adalah jumlah masyarakat yang menuju tempat yang biasanya menimbulkan kerumunan massa akan dibatasi. Dan dianjurkan untuk beralih ke online demi menghindari adanya kerumunan massa melalui metode phsycal distancing. Salah satunya usaha tempat makan yang bisa beralih ke online dan hanya menerima take away ataupun hanya orderan online saja. Selain itu pembatasan juga dilakukan untuk kegiatan adat dan keagamaan, yang mana kegiatan adat dan keagamaan yang dilaksanakan baik di dalam maupun di luar rumah hanya melibatkan paling banyak 20 (dua puluh) orang dengan menerapkan protokol jaga jarak fisik dan PHBS (Perilaku Hidup Bersih Dan Sehat) (Suni, 2020). 
Pembatasan kerumunan masyarakat ini juga diawasi di posko-posko kecil dengan bantuan pihak prajuru desa adat/banjar. Selain itu petugas melalui bantuan petugas desa adat/banjar (pecalang) membatasi kegiatan kumpul-kumpul warga tanpa tujuan yang jelas, dan petugas (pecalang) biasanya akan meminta warganya untuk bubardan idiam di rumah demi keamanan bersama. Pembatasan ini perlu dilakukan karena melibatkan banyak orang dan seringkali warga tersebut tidak menggunakan masker. Terdapat juga sanksi yang akan dikenakan terhadap masyarakat yang melanggar yaitu sanksi administratif dan sanksi adat dengan bantuan aparat desa adat dan aparat banjar, apabila masyarakat tidak memiliki kepatuhan dan kedisiplinan untuk tetap di rumah dalam rangka mengurangi sebaran virus corona. Sanksi ini dibuat bukan untuk menakuti warga namun untuk keamanan dan kebaikan bersama.

Maka perlu kerja sama dan kesadaran dari warga/masyarakat akan kedisiplinan di situasi pandemi saat ini. Sanksi administratif, setiap masyarakat yang melanggar ketentuan PPKM akan diberikan teguran berupa teguran lisan, perintah berupa keharusan membeli masker, perintah untuk tidak melanjutkan perjalanan, dan/atau tidak dilayani dalam pengurusan administrasi kependudukan. Sedangkan sanksi adat ini diatur sesuai dengan pararem desa adat masing-masing. Jadi setiap desa akan menentukan sanksi adat sesuai dengan desa masing-masing. $\mathrm{Hal}$ ini tentu harus disosialisasikan agar tidak menimbulkan bias terhadap masyarakat.

Kebijakan PPKM ini dapat dikatakan sebagai pencapaian tujuan pemerintah dalam menciptakan keteraturan dan ketertiban masyarakat dapat terwujud. Sesuai dengan konsep kebijakan yaitu kebijakan dibuat dengan tujuan tertentu di masyarakat dan kebijakan diciptakan untuk mengatasi permasalahan publik/masyarakat dengan tujuan dapat mencapai kesejahteraan masyarakat melalui peraturan yang dibuat pemerintah. Maka pemerintah dengan sigap memperhatikan keselamatan masyarakatnya dengan membuat peraturan/kebijakan PPKM atau Pemberlakuan Pembatasan Kegiatan Masyarakat. Kegiatan PPKM ini selain memiliki tujuan mengamankan masyarakat, juga bertujuan menekan angka penularan Covid-19 di Kota Denpasar. Diberlakukannya kebijakan PPKM ini tentu mampu perlahan-lahan mengurangi angka penularan hingga Kota Denpasar dinyatakan sebagai zona bersih bebas virus corona. Sesuai dengan konsep kebijakan yaitu diciptakan untuk menyelesaikan masalah publik, kebijakan dirumuskan atas dasar rasionalitas dan penuh dengan pertimbangan agar tidak menimbulkan polemik atau permasalahan baru. Setiap kebijakan yang dibuat pemerintah berisi aturan/larangan yang mampu menciptakan keteraturan dan ketertiban bagi masyarakat.

\section{B. Permasalahan Sosial Akibat Diterapkannya Pemberlakuan Pembatasan Kegiatan} Masyarakat di Kota Denpasar

Setelah diberlakukannya PPKM ini, tidak terlepas dengan adanya kendala-kendala yang terjadi di lapangan. Beberapa kendala yang timbul akibat adanya PPKM ini yaitu saat pertama kali diterapkannya PPKM, dari beberapa lokasi terjadi kerumunan kendaraan bermotor yang sangat panjang akibat adanya pengecekan yang dilakukan petugas pemerintah dan desa adat. Adapun pengecekan yang dilakukan seperti pengecekan surat jalan, suhu tubuh hingga dilaksanakan rapid test kepada masyarakat yang melewati pos-pos yang tersebar di II titik di 
Kota Denpasar. Dari pantauan di lapangan, sebagian besar masyarakat telah mengerti dan melengkapi diri dengan surat jalan. Namun masih ada masyarakat yang tanpa tujuan jelas keluar tanpa menggunakan masker dan tidak menunjukkan surat, selanjutnya oleh petugas diminta untuk balik arah. Hal ini jelas bertentangan dengan tujuan dari PPKM yang bertujuan untuk mengurangi kerumunan dari masyarakat (Astariyani et all, 2020).

Kendala yang kedua yaitu di awal hanya ada II titik penjagaan yang diberikan untuk membatasi kegiatan masyarakat, kurangnya petugas yang ikut memantau dan juga alat untuk pengecekan membuat PPKM kurang efektif. selanjutnya dengan berbasis desat adat, para pecalang disetiap desa adat juga diturunkan untuk memantau kegiatan masyarakat namun pecalang desa adat tidak dilengkapi dengan sistem pengecekan suhu tubuh sehingga pecalang desa adat hanya bertugas untuk mengawasi saja.

Kendala ketiga yaitu dari kesadaran dan kepatuhan individu masih jadi kendala. Faktanya masih ada sebagian masyarakat yang tidak bermasker ketika bepergian dan masih banyak pula masyarakat yang berkerumun. terlepas dari gencarnya petugas melakukan sosialisasi hingga penindakan sangsi disiplin. Ditambah lagi kondisi dilema sebagian masyarakat dimana masih berjualan secara sengaja dengan alasan ekonomi karena bila tidak berjualan mereka tak bisa memenuhi kebutuhan keluarganya. Mengingat tidak semua masyarakat terima bantuan jaringan pengaman sosial. Pada saat ini, berdasarkan data pasien positif yang terkonfirmasi di Kota Denpasar, kurva kasus Covid-19 masih terus meningkat (Dinas Kesehatan Provinsi Bali, 2021). Secara kumulatif, kasus Covid-19 di Kota Denpasar per tanggal 10 Juli 2021 sebanyak 809 kasus positif, rinciannya adalah 354 orang sembuh, 443 orang masih dalam perawatan, 12 orang meninggal dunia. Sementara keberadaan Orang Tanpa Gejala (OTG) hasil tracing GTPP secara kumulatif sebanyak 1.697 orang. Orang Dalam Pemantauan (ODP) tercatat 56 orang dan Pasien Dalam Pengawasan (PDP) sebanyak 89 orang (Balipost, 202I). Hal tersebut tentu sangat membuat masyarakat khawatir dan membuat kesan bahwa pemerintah belum sigap dalam menyelesaikan masalah Covid-19 ini. Diterapkannya kebijakan PPKM hanyalah salah satu pilihan dalam rangka melakukan tindakan mengurangi risiko bertambahnya korban. Oleh sebab itu perlu kebijakan-kebijakan baru yang lebih baik dalam memutus rantai penyebaran Covid-19 ini terutama dalam penyebaran transmisi lokal di terutama dalam lingkungan dalam Kota Denpasar.

\section{KESIMPULAN}

Berdasarkan uraian pembahasan maka dapat disimpulkan, penerapan kebijakan PPKM dalam penanggulangan wabah Covid-19 di Kota Denpasar sudah berjalan efektif. Dilihat dari rangkaian pengawasan dalam kegiatan PPKM ini mulai dari pengawasan penggunaan masker, larangan masyarakat tanpa tujuan yang jelas, pengawasan kendaraan berpenumpang penuh dan aktivitas kendaraan barang, pengawasan kerumunan masyarakat dan tempat makan, restoran, rumah makan, cafe, warung makan, depot, pedagang kaki lima usaha makanan dan minuman, dan mall yang hanya diperbolehkan buka hanya sampai jam 9 malam.

Keterlibatan pihak desa adat sangat
membantu program pemerintah dalam
menanggulangi Covid-19, dikarenakan pihak
pengurus desa melalui prajuru banjar lebih
memahami situasi dan kondisi masyarakat di


lingkungannya. Keterlibatan instansi lain seperti TNI/Polri sangat membantu demi terciptanya keamanan serta ketertiban selama kegiatan PPKM berlangsung. PPKM atau Pemberlakuan Pembatasan Kegiatan Masyarakat ini bertujuan untuk memutus rantai penyebaran virus corona yang terus meningkat. Melalui berbagai rangkaian pengawasan yang dilakukan mulai dari hal yang kecil hingga pengawasan kegiatan dalam jumlah besar. Kebijakan PPKM memerlukan dukungan dan kesadaran dari masyarakat untuk mentaati, disiplin guna mensukseskan program pemerintah.

\section{UCAPAN TERIMA KASIH}

Penulis mengucapkan terima kasih kepada tim peneliti yang telah banyak membantu sehingga penelitian ini selesai dengan baik. Kepada I Nyoman Sunarta dan LP2M Universitas Pendidikan Nasioanl Denpasar selalu suport kepada kami untuk tetap produktif dibidang penelitian dan publikasi.

\section{REFERENSI}

Astariyani, N.L.G., Arjani, N.L., Dewi, C.I.D.W.P. (2020). Pengaturan Pengarusutamaan Gender Sebagai Bentuk Siklus Perencanaan Pembangunan Bali. Seminar Nasional Sains dan Teknologi (SENASTEK).

Balipost. (202I). Hari Pertama Pemberlakuan PPKM Denpasar, Pemeriksaan Digelar di 8 Titik Pintu Masuk. Retrievedifrom http://www.balipost.com/news/.

Harahap, D. A., \& Bandung, U. I. (2020). Pembatasan Sosial Berskala Besar (PSBB) Menangani Pandemi COVID-19 dan Tren Pembelian inline.(April).https://doi.org//0.13 |40/RG.

Kompas. (202I). PPKM Denpasar Hari Pertama, Terjadi Penumpukan Kendaraan, 100 Pengendara
Diminta Putar Balik. Retrieved from https://regional.kompas.com/read/.

Miharja, M., Salim, E., Nachrawi, G., Putranto, R. D., \& Hendrawan, A. (202I). Implementation of Emergency Public Activity Restrictions (PPKM) in Accordance With Human Rights and Pancasila Principles. Budapest International Research and Critics Institute (BIRCl-Journal): Humanities and Social Sciences, 4(3), 68556866.

Peraturan Wali Kota Denpasar Nomor 32 Tahun 2020 tentang Pembatasan Kegiatan masyarakat Di Desa, Kelurahan dan Desa Adat dalam Percepatan Penanganan Corona Virus Disease 2019 (COVID-19).

Permadhi, P. L. O., \& Sudirga, I. M. (2020). Problematika Penerapan Pembatasan Kegiatan Masyarakat (Pkm) Kota Denpasar Berbasis Adat Dalam Upaya Penanganan Covid-19. Prosiding Webinar Nasional Universitas Mahasaraswati Denpasar 2020, 55-60.

Putranto, R. D., Nachrawi, G., Miharja, M., Bayan, M. M. Y., \& Pah, J. M. (202I). State Responsibility for the Citizens in Indoensia's Covid-19 Pandemic. Budapest International Research and Critics Institute (BIRCl-Journal): Humanities and Social Sciences, 4(3), 69136923.

Saragih, M. Y., \& Andrabi, J. A. (202I). The Role of Islamic Journalistics in the Implementation of Community Activities Restrictions (PPKM) Covid19. SIASAT, 6(3), I37-150.

Pujaningsih, N. N. (2020). Penerapan Kebijakan Pembatasan Kegiatan Masyarakat (Pkm) Dalam Penanggulangan Wabah Covid-19 Di Kota Denpasar. Moderat: Jurnal IImiah IImu Pemerintahan, 6(3), 458-470. 
Suni, N. S. P. (2020). Kesiapsiagaan Indonesia Menghadapi Potensi Penyebaran Corona. Pusat Penelitian Badan Keahlian DPR RI, XII (3), il3-I8. Diterbitkan, Ciamis: Program Pascasarjana FISIP UNIGAL.

Zahrotunnimah, Z. (2020). Langkah Taktis Pemerintah Daerah Dalam Pencegahan Penyebaran Virus Corona COVID-I 9 di Indonesia. SALAM: Jurnal Sosial Dan Budaya Syar-I, 7(3).https://doi.org/10.15408/sjsbs.v7i3.1513. 